\title{
The UNESCO FRIEND-Water program: accelerates, shares and transfers knowledge and innovation in hydrology across the world in the frame of the Intergovernmental Hydrological Program (IHP)
}

\author{
Gil Mahé ${ }^{1}$, Gamal Abdo ${ }^{2}$, Ernest Amoussou ${ }^{3}$, Telesphore Brou ${ }^{4}$, Stephan Dietrich $^{5}$, Ahmed El Tayeb ${ }^{6}$, \\ Henny van Lanen ${ }^{7}$, Mohamed Meddi ${ }^{8}$, Anil Mishra ${ }^{9}$, Didier Orange ${ }^{10}$, Thi Phuong Quynh Le ${ }^{11}$, \\ Raphael Tshimanga ${ }^{12}$, Patrick Valimba ${ }^{13}$, Santiago Yepez ${ }^{14}$, Andrew Ogilvie ${ }^{15}$, and Oula Amrouni ${ }^{16}$ \\ ${ }^{1}$ HSM, Université Montpellier, IRD, MSE, 300 Av. E. Jeanbrau, 34090 Montpellier, France \\ ${ }^{2}$ Water Research Center, University of Khartoum, Khartoum, Sudan \\ ${ }^{3}$ Department of Geography and Spatial Planning, University of Parakou, - Parakou, Benin \\ ${ }^{4}$ Dept. de Géographie, Laboratory OIES (Océan Indien: Espaces et Sociétés), Université de La Reunion, \\ 15 avenue René Cassin, CS 92003, 97744 Saint Denis CEDEX 9, La Réunion \\ ${ }^{5}$ International Centre for Water Resources and Global Change, Federal Institute of Hydrology, \\ P.O. Box 200253, 56002 Koblenz, Germany \\ ${ }^{6}$ The National Water Research Center Ministry of Water Resources, Irrigation and Electricty, Khartoum, Sudan \\ ${ }^{7}$ Hydrology and Quantitative Water Management Group, Wageningen University, \\ Droevendaalsesteeg 4, 6708 PB Wageningen, the Netherlands \\ ${ }^{8}$ National Superior School of Hydraulics, Blida, Algeria \\ ${ }^{9}$ UNESCO, Division of Water Sciences, 7, place de Fontenoy, 75352 Paris 07 SP, France \\ ${ }^{10}$ Eco\&Sols, Université Montpellier, IRD, INRAe, CIRAD, SupAgro, LMI iESOL, \\ Centre ISRA-IRD Bel Air, Dakar, Sénégal \\ ${ }^{11}$ Institute of Natural Product Chemistry, Graduate University of Science and Technology, \\ Vietnam Academy of Science and Technology, 18 Hoang Quoc Viet, Cau Giay, Hanoi, Vietnam \\ ${ }^{12}$ Congo Basin Water Resources Research Centre/CRREBaC, Univ. of Kinshasa, \\ P.O. Box 117 KIN XI, Kinshasa, Congo \\ ${ }^{13}$ Department of Water Resources Engineering, College of Engineering and Technology, \\ University of Dar es Salaam, P.O. Box 35131, Dar es Salaam, Tanzania \\ ${ }^{14}$ Departamento Manejo de Bosques y Medio Ambiente, Facultad de Ciencias Forestales, \\ Universidad de Concepción - UdeC, Concepción 407374, Chile \\ ${ }^{15}$ G-EAU, IRD, AgroParisTech, BRGM, CIRAD, INRAe, SupAgro Montpellier, Montpellier, France \\ ${ }^{16}$ National Institute for Marine Sciences and Technologies, Carthage Salammbô, Tunis, Tunisia \\ Correspondence: Gil Mahé (gil.mahe@ird.fr) \\ Published: 16 November 2021
}

Abstract. The FRIEND-Water program (FWP) is the oldest and the most transverse program (i.e. Flagship Initiative) within the Hydrological Intergovernmental Program (IHP) from UNESCO. FRIEND means "Flow Regimes from International and Experimental Network Data". The FWP is dedicated to allow large communities of hydrologists and associated disciplines to collaborate across borders on common shared data and scientific topics which are addressed through large world regions. The program has evolved in its 35 years of existence. There are 8 large regions in the world which gather tenths of hundreds of researchers, and organize events following several research topics defined according to each region priorities. The FWP is chaired by a scientific committee gathering regional coordinators and thematic experts. Each region gives its research priorities which 
evolve according to the projections given by the member States during the IHP council every year. The future activities of the FWP are defined by the upcoming IHP IX program and with the support of the newly created Montpellier UNESCO Category II Center ICIREWARD, acting as FWP Secretariat.

\section{Introduction}

At the start in 1985 the purpose of the FWP was to allow researchers from different countries and regions to conduct studies on shared river basins, with the support of national hydrological services which agreed to share data with the UNESCO FRIEND-Water groups. Over time, most hydrological services stopped sharing data and this is the current challenge to reactivate the data exchange through new platform facilities. The FRIEND-Water regional groups develop studies on research topics specific to their regions. However, some topics are common to several regions such as floods and low flows/drought, snow and glacier hydrology, erosion/sedimentation and water quality. The ecohydrology theme is of increasing interest among the different regions. Its development within the FWP is in close link with the Ecohydrology program of UNESCO IHP. A special session on ecohydrology has been organized during the last Global FRIEND-Water conference in Beijing in November 2018, and further joint meeting are scheduled. In addition to the Ecohydrology programme, there are several other thematic IHP programmes and initiatives such as International Flood Initiative (IFI), International Sediment Initiative (ISI), International Drought Initiative (IDI), World large River Initiative (WLRI) and UNESCO's programme for Water and Development Information for Arid Lands - a Global Network (G-WADI). It is important that FRIEND-Water should positions itself in a way that maximises complementarities and synergies and minimizes duplication with other IHP initiatives and programmes. The activities of the program are developed through different meetings, workshops or conferences, together with training sessions and field trips. Many of the communications presented during the workshops are published in special issues of regular indexed journals and conference proceedings of IAHS, the International Association of Hydrological Sciences, with which FRIEND-Water is closely linked since the start. Furthermore, FRIEND-Water intends to promote the dialogue between the scientific community, the user community and policy makers in studies related in the context of SDGs and Paris Agreement. Ongoing research addresses groundwater, in particular shortage under dry environmental conditions. The Groundwater Drought Initiative (GDI) has been established across Europe. Largescale studies explored how groundwater pumping, which is vitally important for irrigation and associated food security, decreases streamflow globally, and estimate where and when environmentally critical stream flows will no longer be sustained. Furthermore, hydrological knowledge is more and more used to study impacts of natural hazards on socioeconomic and environmental conditions. There is special attention to the relationship between droughts and/or floods and people. Classical bottom-up approaches which include vulnerability are combined with top-down approaches to change from reactive to pro-active risk management. In this context, study of multi-hazards (coinciding and cascading) is a focal area that aims at development of Early Warning Systems, including understanding, identification, monitoring and forecasting. Other studies deal with the processes of transfer and transformation of matter within the large global hydrological systems. With emphasis on rivers, lakes and reservoirs, trying to understand the balance of sediments and their role in primary production, and in particular water quality. Currently, the different groups of the FWP are relying on new space technologies to observe the spatial and temporal dynamics of these processes. A particular case is the use of satellite images as a tool to densify and extend in situ observations which were traditionally measured in a punctual manner at hydrological stations. This new type of approach, applied at different scales, allows balances to be made which help to understand the natural variability of the systems, quantifying the transfer processes and determining possible impacts, driven either by climatic or by anthropogenic causes. Based on the thematic scientific feedback FRIEND-Water should also provide feedback to address hydrology and human nature interactions in the context of complex water management problems.

Moreover, more studies are ongoing which use spatial climate (gridded) input data into hydrological models to assess suitability of generated streamflow for rainfed agriculture, engineering designs of hydraulic and flood protection structures and ecological conservation. The emphasis is to understand suitability of global climate data in real life applications. This data increasingly becomes available to patch gaps in observational climate records and useful in large ungauged catchments/basins but needs verification in different areas as some is derived from coarse networks of observational stations particularly in Africa.

During the current phase of the FRIEND-Water program (2018-2022) (Fig. 1), it has been recommended to all regional groups to promote training sessions and workshops on the theme of spatial hydrology, which is a research field that can bring future major improvements in hydrological sciences, closely related to the processing and share of huge hydrological databases. It has been also recommended to develop the information about the program to a large public, including scholars and civil society and to closely fit with 


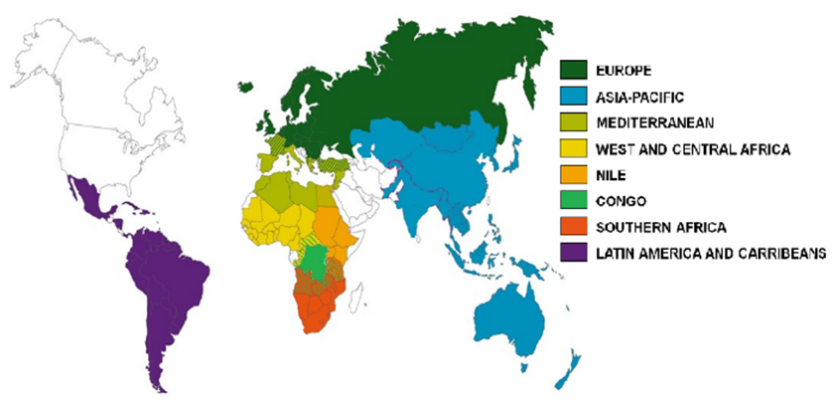

Figure 1. The 8 regions of the FRIEND-Water program during the phase 2018-2022.

the orientations of the Strategic Plan for the IHP-IX that was adopted by the 24th Session of the Intergovernmental Council of the UNESCO IHP (UNESCO, 2021).

\section{Regional FRIEND-Water cooperations}

\subsection{AMIGO FRIEND-Water}

Currently, the main challenge will be to implement a standard framework for assessing the conditions and evolution of rivers, considering hydrogeomorphological and ecological properties, which should be a priority for all future river management works. Recently, we have started to apply the River Styles framework to carry out hydrogeomorphological studies with an approach adapted to the local reality, focusing on the development of protocols and procedures (many of them automated using GIS/RS techniques) to assess the condition of rivers in South America and the Caribbean (Gallay et al., 2019). This would allow prioritizing rivers in terms of their conservation and restoration, as well as orienting sustainable management strategies in them, where the hydrogeomorphological factor is sometimes incorporated in a limited way in most of the engineering projects developed along the riverbanks (Nardini et al., 2020). This approach must necessarily take into account in a comprehensive manner the different morphologies and varieties of rivers and also the particular nature of human disturbances (e.g. water diversions, reservoirs, gravel mining, urban sprawl, forestry activities, among others) and their distribution across regions.

South American region has a strong vulnerability face to climate change and it affects not only rainfall regimes and temperature extremes, but also water resources systems. Many countries experiment a serious concern with glacier retreat since last decades caused by a regional warming. In general, Andean mountain catchments are also being affected by anthropogenic interventions, affecting water resources availability and water security (Laqui et al., 2018; Yepez et al., 2017, 2018). In Andean context, some hydrological processes are still unknown and misunderstood because of data scarcity, increasing the gap between decision makers and develop. Beside, this alteration of the hydrological cycle is ex- acerbated with large scale climatic phenomenon as El Niño, producing droughts or floods, being more remarkable on both sides of the Andes, over Pacific coast and Amazonian regions (Rau et al., 2018). Therefore, researches are expected to provide reliable databases, scientific evidence and communicate to improve water management practices.

The Andes of South America and their surrounding basins are regions sensitive to climate change and tectonic events. Feedback between climate, tectonics and anthropogenic activities has a profound impact on the current landscape. Additionally, such processes have a significant impact on the biodiversity of species. Our investigations use thermochronology and quantitative geomorphology techniques to model the landscape evolution and analyze the influence of these interactions on biodiversity. A combined effect of increased tectonic, climatic and anthropogenic activities produces an increase in the sedimentation rates of rivers. Through numerical modeling, thermochronology and cosmogenic nuclides it is possible estimate long-term erosion rates and compare them with short term (or current) erosion rates in order to discriminate the events that generate these increases (Ferreira Araújo et al., 2017).

Land-use changes lead to disturbances on weathering processes and nutrient cycles. Chemical weathering of continental rocks plays a central role in regulating the carbon cycle and the Earth's climate, as well, in the supplying of essential nutrients, such as N, P and trace metals, for the ecosystems. However, man-induce changes on land use and hydrological features associated with natural resources exploitation, water extraction, damming and urbanization can alter water-rock interaction times, flow regimes, sediment transport (Carretier et al., 2018; Laraque et al., 2019), which in turn, affect natural weathering regime and elemental biogeochemical cycles. Human activity can also impact weathering via acid rain. Burning of fossil fuels releases nitrogen and sulfur compounds that later form nitric and sulfuric acids in rainwater. These are stronger acids than carbonic acid and they accelerate rock dissolution and negatively impact upon ecosystems. Our study aims to understand how climate change and anthropic actions can modify weathering processes at local and global magnitudes, at short and large scale-times, and impact aquatic ecosystems (Moquet et al., 2018).

\subsection{CONGO FRIEND-Water}

As referred to the study of Alsdorf et al. (2016), the Congo River basin although being the second largest river in the world by the discharge, it remains largely understudied. It is thus very important to strengthen the research and knowledge capacity in this region of the world, based on the emerging new research teams over the many countries that share the Congo River (Beighley et al., 2019; Trigg and Tshimanga, 2020). The Congo River Basin exhibits tremendous heterogeneities, out of which it emerges as an intricate system where complexity will vary consistently over time and space. 
Increased complexity in the absence of adequate knowledge will always result in increased uncertainties. One way of simplifying this complexity is through an understanding of organisational relationships of the landscape features, which is termed here as catchment classification (Tshimanga et al., 2021). This is one of the major tasks to start with at the international level, in order to develop further multidisciplinary studies on the basis of this global knowledge shared among all teams. During the past 12 months, there has been a first attempt to establish a framework of catchment classification using an a priori approach. Various methods, including GIS and multivariate analyses, were combined to define the subbasin units and group them in homogeneous regions. A set of 1740 catchment units were partitioned across the whole Congo River Basin, based on a set of comprehensive criteria, including the natural break of the elevation gradient (199 units), inclusion of socio-economic and anthropogenic systems (204 units), and water management units based on traditional (socio-hydrology) nomenclature of the rivers within the basin (1337 units). The identified catchment units were used to assess existing datasets of the basin physical properties, necessary to derive descriptors of the catchments characteristics. Assessment of relationships between physical basin attributes and the catchments through PCA showed that 15 variables out of 26 initially selected contained the information necessary to explain the spatial distribution and grouping of the sub-basins. These 15 variables were included in a cluster analysis using unsupervised classification (hierarchical agglomerative clustering), which identified 11 groups of homogenous catchments based on the use of the environmental descriptors derived from the available physical basin property datasets. This constitutes therefore an a priori clustering of the catchment classification framework for the CRB and should be considered as an initial phase of the iterative process of catchment classification. This a priori clustering will be further used to derive functional relationships of the catchments, necessary to enable hydrological prediction and water management in the basin. The framework is therefore an efficient tool that will help synthesize our understanding of the interaction between climate variability, catchment characteristics (e.g. vegetation, soils, topography) (Mushi et al., 2019) and the resulting hydrological response. It is also a crucial step in improving predictions in ungauged basins, and the new insights of the Congo river hydrology obtained from the most recent field campaigns will help improve the accuracy of the satellite derived hydrological data (Carr et al., 2019). Within FRIEND-Water-UNESCO, we intend to promote the use of this framework to address the challenge of generalizing knowledge derived from local observations and understanding of the catchment response characteristics, as well as the underlying process controls; to provide guidance for measurement and modelling, and constraints for predictions in ungauged basins and to estimate impacts of environmental changes.

\subsection{EURO FRIEND-Water}

Closely inter-related key issues and challenges to large-scale hydrology were identified to improve prediction of hydrological systems behavior (surface/sub-surface) on large spatial and time scales (i.e. continental - multidecadal) under changing environmental conditions (Massei et al., 2018; Kingston et al., 2020). Large-scale hydrology depends on interactions across the ocean-atmosphere-vegetation/soil/aquifer system. Detection of climate indices and large-scale patterns directly from hydrological data (Renard and Thyer, 2019) is required. Characterizing non-stationarity and time-scale dependence of large-scale relationships also appears fundamental (Dieppois et al., 2013). Other remaining challenges to be studied are how climate system models are capable of representing large-scale relationships at different temporal scales, or how to assess whether model performance in simulating hydroclimatic variables results from realistic large-scale climate processes, or from other compensating biases (Dieppois et al., 2019). Improved knowledge on large-scale relationships would also lead to more skilful hydrological forecasts (Lavers et al., 2017).

As catchment characteristics play a dominant role in filtering out climate variability on river flow, including hydrological extremes (Van Lanen et al., 2013), efforts need to focus on improving representation of key hydrological processes on the large scale, very often oversimplified in largescale models. For instance, lateral re-distribution by hillslope processes, landscape (Laizé and Hannah, 2010) or subsurface heterogeneities (Hartmann et al., 2017), or the role of groundwater on large-scale hydrological response (Sidibe et al., 2019) needs to be accounted for.

The last decade, substantial progress has been on the detection and projections of hydrological extremes, including drought (e.g. Stahl et al., 2012; Prudhomme et al., 2014). Emerging topics have been identified, such as flash droughts, multi-year droughts (where these were not reported before), cold-climates' droughts, anthropogenically-enhanced droughts (Teuling et al., 2016).

Another major challenge that remains is the attribution of the causes and processes leading to low flow (events), streamflow droughts, and intermittent flow. These necessities improved knowledge on how weather anomalies eventually end up as hydrological drought (groundwater, streamflow), i.e. how climate and catchment controls, and human drivers affect drought development and termination (Van Loon et al., 2016). Groundwater, as an important catchment control, requires more attention (Stoelzle et al., 2014). A step forward is the pan-European Groundwater Drought Initiative (GDI ${ }^{1}$ ) that recently has been established. Furthermore, attribution calls for further development of hydrological models that dynamically consider changing environmental conditions im-

\footnotetext{
${ }^{1}$ https://www2.bgs.ac.uk/groundwater/waterResources/ groundwaterDroughtInitiative/home.html, last access: 6 January 2021)
} 
plying focus on more process-based rather than a calibrationbased modelling approach.

Early Warning Systems (EWS), incl. monitoring and forecasting, will be further developed to mitigate and adapt to hydrological extremes and to enable rapid pro-active riskmanagement rather than a re-active approach. In this context, a critical appraisal of indices and indicators will be done. Furthermore, hydrological knowledge is more and more used to study impacts of drought on socio-economic and environmental conditions (Stahl et al., 2016; Blauhut et al., 2015; Sutanto et al., 2019a). Classical bottom-up approaches, which use hazard, exposure and vulnerability as a basis are combined with top-down approaches to change from reactive to pro-active risk management. In this context, study of multihazards (coinciding and cascading) is becoming a focal area (Sutanto et al., 2019b) in the further development of EWS.

Transnational hydroclimatic data are fundamental to investigate hydrological extremes and large-scale variation in hydrology. Flow data from European river will be regularly updated, as part of further development of information systems the Global Runoff Data Centre (GRDC) and other relevant data centres and observational networks of the Global Terrestrial Network for Hydrology $(\mathrm{GTN}-\mathrm{H})^{2}$ are involved in. We will encourage hydrometeorological services to provide these data. Large-scale hydrological data rescue (Le Gros et al., 2015) needs continuation, as well as, reconstruction of long-term, high-resolution climate datasets (Devers et al., 2020), and use of remote sensing products (e.g. GRACE). Compatibility between, or merging of, national-scale datasets (Caillouet et al., 2019) is planned to be further investigated to contribute to large-scale databases.

\subsection{FRIEND-Water AP}

In Asia Pacific region, water resources in many countries are affected by climate change (Yang et al., 2019). Increasing dry season duration, longer and more serious droughts (Wei et al., 2019), could cause water shortage occurred on a large scale and reduce water quality, affect strongly water security and sustainable development. Besides, rising sea levels lead to flooding in the delta and coastal areas, increasing saline intrusion in estuaries and coastal plains and causing erosion and sedimentation to upset the natural and ecological balance (Li et al., 2018; Xi et al., 2019), seriously affecting coastal areas. Thus, researches are hoped to provide useful information and solutions related to ensuring water security in the context of clear climate change today.

The downstream of international rivers, is often suffering from water-related disasters (Try et al., 2018), facing water scarcity and declining water resources due to overexploita-

\footnotetext{
${ }^{2} \mathrm{GTN}-\mathrm{H}$ is a federation of global water data centres, inter alia the GRDC and GEMS/Water Data Centre and operates under the auspices of WMO and the Global Climate Observing System GCOS, http://www.gtn-h.info (last access: 6 January 2021)
}

tion, thus water resources in the Asian countries are hiding many unsustainable factors for development (Kondolf et al., 2018). Water scarcity and water shortage will increase sharply compared to today and most river basins are in a state of stress on water use (Hiraga et al., 2018), especially during the dry season. Water tensions will be severe in key economic basins (Kositgittiwong et al., 2017). Thus, one important topic in Asia is how to reduce the stress on water use, especially during the dry season?

Due to rapid increase of population, industrial and expanded agricultural production, pollution of surface water has been increased in both level and scale (Zhang et al., 2018; Nguyen et al., 2019). Water is available in many places but cannot be used due to its poor quality. Especially, surface water and ecohydrosystem in many urban areas, and industrial parks has been seriously affected due to the untreated wastewater or incompletely treated wastewater. In some countries in Asia Pacific, lack of large investment in industrial and urban wastewater treatment, no effective mechanisms and policies to reduce water pollution, over use of fertilizers and chemicals in the agricultural sector ... have accelerated pollution level in this region. Thus, the development of researches related to minimize water degradation is firstly needed (Le et al., 2017; Uk et al., 2018).

Rapid increase in water demand accelerates the groundwater exploitation, leading to over-exploited. Groundwater level in some areas has been continuously reduced and more important, groundwater quality is at high risk of pollution (e.g. As) (Hoa et al., 2020). Thus, studies should be focused on providing information concerning reasonable exploitation of groundwater and protection of both quantity and quality of groundwater.

\subsection{FRIEND-Water AOC}

In West and Central Africa, as in other regions of the world, studies have shown a growing risk of extreme events (excess rain and temperature, lack or scarcity of rain, etc.) with the advent of global warming of the planet, but which is not without consequences for the capacities of production systems and water resources (Sidibe et al., 2018, 2020; Amoussou et al., 2020). Thus, we are witnessing the destruction of natural and human ecosystems and the loss of biological diversity by overflowing waters (flooding), very marked drying up of beds and anthropogenic pressure. Changes in precipitation and temperature, as well as non-linear effects on humidity, evapotranspiration and soil, affect the quantity and quality of water resources, agriculture, fishing and livestock (Amoussou, 2010; IPCC, 2013) and therefore on the life of the local population.

This climate change/variability coupled with demographic change and land degradation affects the functioning of the terms of the hydrological balance and the frequency of extreme events and therefore the water levels in the lakes (Zare et al., 2017), the hydraulicity downstream of the structures, 
the modes of resource use in the developed sites, the dams, the safety of river water and the feminine management of the resource. To this end, it is important to accentuate studies on hydrological standards, intensity, duration and frequency (IDF) of storms, cold or heat waves on the one hand, the increase of the extent of regions affected by drought and unexpected floods, with unevenly distributed consequences for many regions of the world, particularly in developing countries (Parkes et al., 2019), and especially in Sahel (Descroix et al., 2018). In order to overcome these hydrological catastrophic events, the Friend AOC network with the support of the Research Institute for Development (IRD) has written and submitted a GDRI project entitled: "Hydrological Standards in West Africa and Power station for a better design of hydraulic structures",

Hydrological networks quality has been decreasing continuously since decades in the region, despite very huge support from international organization. Thus spatial hydrology development and use are of utmost importance in the region, and the first studies since some years are very encouraging (Bogning et al., 2020). It must be associated with a significant increase of data sharing with large communities of researchers (Dieulin et al., 2019).

In addition, in the lagoon system of the coastal regions, the alternation of high and low water generates sometimes a predominance of the sea current with a strong sediment transit, and sometimes a predominance of the river current with addition and deposition of sediment on the shore. The mechanism of flood transport of sediments from developed basins occurs from upstream to downstream with the deposit of fine particles at the entrance to the floodplains. In addition, in periods of high water, the river current which feeds the lagoon systems increases and exceeds in force the coastal or lagoon current, there is therefore an increase in the solid charge and deposit of coarse sands due to the weakening of the current. For this purpose, there is an elevation of the bottom of the bed on one side and the digging of the other side related to the reinforcement of the current. All of this creates disturbances with the rising tide, causing flocculation and rapid deposition of sediment in the lagoon system, which causes the decline in fishery productivity of water bodies.

The socio-economic and ecological importance of the coastal zones of West and Central Africa in general and lagoon in particular (Adeaga et al., 2017) in a context of environmental crisis leads to a reflection on the functioning, the evolution as well as the management of the use of resources of lagoon spaces. Thus, the animation of this new theme with that of eco-hydrology is necessary to better characterize the hydrological and sedimentary dynamics of the environment in the context of global changes, and sea-level rise, already impacting most coastal areas around the world.

\subsection{FRIEND-Water SA}

Monitoring of water surfaces and floods by remote sensing Radar is a very important issues for hydrological studies. In the case of Mozambique and Tanzania in the semi-arid rural areas of southern Africa where the availability of water is a major issue for agriculture, the monitoring of surface water is particularly important (André et al., 2016; Mzava et al., 2019), particularly in ungauged watersheds. In addition, large cities, due to the weakness of water facilities, are particularly vulnerable to large-scale floods. Radar images are particularly well suited to the seasonal observation of water surfaces in tropical environments because the Radar signal is freed from cloudiness, which on the contrary constitutes a major limitation of the use of optical images in these environments. In addition, Radar images are very robust for detecting surfaces in water (source, etc.), the signal backscattering being very low (almost zero). On a Radar image, the pixelwaters are those whose values are less than 0.05 .

The possibilities offered by the European Space Agency (Copernicus) thanks to its Sentinel 1 sensors make it possible to have at least one image per month. Sentinel 1 (Radar) monthly time series of images can thus be created. Management of hydro agricultural resources in ungauged watersheds: the case of the Kilombero watershed in Tanzania (Johansson and Abdi, 2020). The Kilombero watershed is a territory which potential in terms of water and agricultural resources make it a national issue. Indeed, the Tanzanian government wants to make these vast flood plains the granary of Tanzania through an agricultural irrigation project. At the same time, the Tanzanian government plans to build a large hydroelectric dam, downstream from the Kilombero watershed, which will mobilize almost $66 \%$ of the water resources in the watershed. The management of water in this watershed could therefore arise in terms of competing for access to water between these two projects of national importance. Consideration should be given so that agricultural production in the plain upstream also allows optimal production of hydroelectricity downstream from the watershed. In addition, to better manage water resources, it is important to have a good hydro-environmental and socio-economic database. However, since the 1980s, no hydro-environmental and socioeconomic measures have been taken on this $35000 \mathrm{~km}^{2}$ watershed. The first step will be to create a database (hydrological, climatic, land use, agricultural, socio-demographic and tourist) in order to better understand the functioning of this territory, which constitutes a national economic issue. In a second step, we will model the environmental dynamics from the database thus created. From an operational perspective, the database will assist in the management of water resources in the Kilombero watershed.

A second research direction which is of major importance is the impact of climate variability and human pressures on surface conditions. A follow-up of the relationships between climatic variability and vegetation must be first analyzed to 
understand the natural dynamics of the landscape (Brou et al., 2018; Brou, 2019). This study is based on the assumption of an increasing vulnerability of forest ecosystems due to changes in the climate regime recorded during the last thirty years.

To conduct this study, it is important to update the knowledge of climate parameters, in particular the amount of rain and its distribution throughout the year. Equally important is the study of the trend and frequency of climate data for the longest series of observations available on the watershed. The study of the sensitivity of vegetation to climatic variations is carried out by means of a rain/NDVI co-variation analysis. Several parameters will make it possible to follow the interannual seasonal variability of the vegetation: the start and end dates, the duration, the amplitude, the maximum of the vegetative season (Boussougou et al., 2017). To better understand local dynamics, Sentinel 2 images should be used. The comparison of images from several dates will allow to assess, by site, the levels of transformation of landscapes in relation to the degree of soil degradation.

The use of spatial data represents an important skill to strengthen the capacities of students in the monitoring and management of water resources at better spatio-temporal resolutions. In the context of global environmental changes, this training in geomatics is intended, ultimately, to strengthen the capacities of master and doctorate students in hydrology and geography in the field of monitoring water resources through the use of data spatial. This geomatics training is part of a favorable regional and international context marked by the availability of a large quantity of Sentinel, Landsat satellite images in particular. In addition, the development of GPS makes it possible to collect terrain data with more precision. The objective is to allow users in environmental sciences, environmental managers or developers, to acquire the conceptual bases, methods of use and processing of remote sensing data. Applications in the field of water resources and coastal zones must be developed.

\subsection{MEDFRIEND-Water}

The Mediterranean basin is characterized by limited and unevenly distributed water resources and a considerable development of anthropogenic activities. Hydro-climatic projections predict a decrease in average annual rainfall and runoff in this region of the world. Moreover, water demands have doubled since the 1950s and are expected to increase with the expansion of irrigated areas and urban areas. For the Mediterranean basin, according to climate projections, the temperature will increase by 2 to $4{ }^{\circ} \mathrm{C}$ and rainfall will decrease by $4 \%$ to $30 \%$ by 2050 . This decrease in precipitation will cause a decrease in flow for all four seasons. As a result of these climate changes, extreme peak flows are expected to increase dramatically. Hydrological droughts will worsen in summer, mainly in the Mediterranean region. The most extreme events are expected to occur in summer, with extreme droughts in the Mediterranean region. The Mediterranean countries are expected to face increasing water shortages. These projections also lead to an increase in the number of days per year when river flows will be below the minimum in the Mediterranean regions. Climate projections show a decrease in groundwater resources in the Mediterranean basin. Overexploitation of groundwater in Mediterranean countries will lead to alarming levels of groundwater and increased pumping costs. Also, soil water stress conditions will drastically reduce agricultural production yields. Water consumption is already higher than water availability and is expected to be critical for global warming. In the countries on the southern shore of the Mediterranean and Spain, the situation of water resources will become more unsustainable in the future, which will have a negative impact on the availability of water resources to ensure sustainable development in these countries.

Thus, the major research topics to deal with in priority in the Mediterranean area are:

- Extreme events or hydrological extremes and waterrelated disasters (Tramblay and Somot, 2018; Hadour et al., 2020);

- Erosion and transport of solids (Hallouz et al., 2018; Kotti et al., 2018);

- Integrated Water Resources Management (Marignani et al., 2017; Khater et al., 2019);

- Groundwater and global changes (Kuper et al., 2017; Dubois et al., 2018; Erostate et al., 2020);

- Ecohydrology (Amrouni et al., 2019; Ben Moussa et al., 2019);

- Water in agriculture (Venot et al., 2017; Kuper et al., 2018; Reca-Cardena and Lopez-Luque, 2018).

Transversal topics will be of high importance for instance water in the city, education to water questions, participatory science, transition toward a more ecological approach of the water cycle and use. It will be developed through improved connections with all the sectors of the society, and the development of new tools to communicate and disseminate knowledge, mainly web-based.

A high-level challenge is also to improve the codevelopment of research projects between countries of the Mediterranean and SubSaharan countries, and the Water family of UNESCO is a very good support to this.

\subsection{NILE FRIEND-Water}

The Water Research Centre, University of Khartoum is a multidisciplinary research and capacity building center established by the University of Khartoum in 2009 with the aim of conducting multi-disciplinary research and development studies addressing the challenges related to water and 
environmental management in Sudan and the region (Salih, 2018; Basheer et al., 2018). One of the top priority research areas is trans-boundary water management in the Nile basin. Demand for water throughout the basin is constantly growing due to economic development and population growth. Following this rapidly increasing demand, riparian countries have acknowledged the need for joint planning and management. Numerous studies have demonstrated that the river has great potential which, through sustainable and cooperative management and development, could greatly benefit all the basin countries. A research area of specific interest to the Water Research Centre is the Water Energy Food (WEF) Nexus investment and management in the basin. The WEF supply pressures, the growing understanding of the interlink ages between the three resources, and the failure of fragmented management of the different WEF sectors have led to the emergence of such Water-Energy-Food nexus thinking. Although WEF in stressed trans-boundary Basins such as the Nile are subject to high pressure due to competition between riparian countries over the three resources, a systematic understanding of how cooperation between riparian countries impacts the WEF nexus is still lacking (Wheeler et al., 2018; Basheer and Elagib, 2019). Another trans-boundary management challenge is the coordinated operation and management of new water-related infrastructure across the basin's international borders. This is particularly true given that water rights are highly politicized and decisions of exploitation are often guided by ambitious national development plans and complex political dynamics. A good example is the Grand Ethiopian Renaissance Dam (GERD) on the Blue Nile which makes cooperative management between the countries of Ethiopia, Sudan, and Egypt an urgent matter. To enhance confidence building and enhance cooperation in the Nile Basin the Water Research Centre has developed a strategy for training and capacity building in Water Diplomacy and Cooperation (Salih, 2019). A number of workshops have been conducted in which participants from the Nile Basin Countries from relevant disciplines were brought together and trained on trans-boundary water governance and institutions, water laws and conventions, concepts of conflict and conflict resolution mechanisms, negotiations and mediation concepts, role of media in water diplomacy, the role of women in water diplomacy and the role in science in supporting negotiations and water cooperation. An important research area in WRC is the study of hydrological extremes. Sudan, being situated on the eastern edge of the African Sahel, is a well-documented region in facing the problems of climatic change/variability and rainfall fluctuations creating severe floods and drought scenarios (Abdo, 2019). Over the past 50 years, Sudan has encountered a number of high flash floods and droughts that have caused widespread damage on a massive scale to infrastructures, agriculture, health and educational sectors, and loss human and animal lives. Other research areas the Centre is involved in include irrigation management and water use efficiency, water harvesting and man- agement of groundwater recharge, urban water management, echo-hydrology, water quality management and groundwater assessment, development and management (Basheer et al., 2019).

In 2014 the WRC was promoted to a Centre of Excellence in Water Research by the Ministry of Higher Education and scientific Research. In 2017 WRC was selected as one of the AU-NEPAD Centers of excellence in water science and technology in Africa and it is now hosting the secretariat of group of centres in central and Eastern Africa. Over the years, WRC has developed scientific collaboration with many universities, research institutions, specialized networks and programs nationally, regionally and internationally. These include UNESCO IHP, Global G-Wadi (Water and Development Information), African G-Wadi, Arab G-Wadi, International Flood Initiative (IFI), International Sediment Initiative (ISI), World Bank-Nile Basin Initiative NBI/, Eastern Nile Technical Regional Office (ENTRO), UNESCO-IHE, Delft the Netherlands, UNECEF, Cologne University of Science and Technology, Germany, Imperial College of Science and Technology, London, UK, Oxford University, Oxford, UK as well as many Regional Universities including Addis Ababa University, Nairobi University, Kenyatta University, Dar es Salam University, Cairo University, and Ain Shams University. WRC has participated in the two phases of the FRIENDWater/NILE project and produced a number of papers in the flood frequency, low flow frequency, watershed management and rainfall runoff modeling components.

\section{Future FRIEND-Water program developments}

\subsection{Ecohydrology}

Ecohydrology and multiscale studies are a key interest for the future FWP. As more and more well known, the stationarity is dead. As more and more known, the Earth is a non-linear complex system. Recent discoveries on the importance of living things and their environmental feedbacks, on the role of homeostatic processes and breakpoints confirm that global warming is only part of the current ecological crisis which is also manifested by the loss of biodiversity, the loss of soil fertility, the water pollution but also the drastic increase in diseases that affect the entire living world. The current COVID19 pandemic is just one more dramatic example! The water cycle is at the center of all of these interlocking systems (Orange and Breil, 2018). Also it becomes obvious to hydrologists that it is essential to cross the scales of spatial studies, from large to small watersheds, and vice versa. Understanding the why of a hydroclimatic rupture and its consequences will therefore require interdisciplinary perspectives. It then appears that the study methods promoted by the ecohydrology must also belong to the research corpus of hydrologists.

Ecohydrology is among the key words of the future FWP directions. Then, related to the goal of the IHP9 to achieve Sustainable Water Management (SWM), the FWP will get 
some interests to incorporate ecohydrology among its key tools. In this context, significant challenges of scientific fields appear to be addressed:

- developing dynamic hydrological models based on changing environmental conditions (e.g. soil-water dynamics) (Hang et al., 2018),

- climate change and sustainable ecological transition (e.g. urban-rural association),

- nature-based solutions as a rising awareness towards environment (e.g. REUSE-Soil-Biodiversity nexus).

- rainwater management in urban areas (e.g. flashfloods).

Ecohydrology is among the key words of the future FWP directions. Then, related to the goal of the IHP9 to achieve Sustainable Water Management (SWM), the FWP will get some interests to incorporate the ecohydrology among its key tools. Active partnership between EcoHydrology theme and the future FWP is scheduled through the opening of demosites. Since 2011 UNESCO-IHP promotes the establishment of various demonstration sites around the world to apply Ecohydrology solutions in watersheds at all scales. Each demonstration site aims to apply Ecohydrology principles and solutions to solve both social and environmental issues (Riaux et al., 2020). These solution-oriented projects and methodologies are shown in a web-platform (http://ecohydrology-ihp. org/demosites/\#demosites, last access: 6 January 2021) to disseminate the acquired information to UNESCO's Member States and the general public. This information is dedicated to allow to applicate SWM in other locations.

Then, it is scheduled to propose the opening of 2 joint EHFRIEND-Water demosites, one in Tunisia dealing with water quality remediation in highly polluted environments (around Bizerte), in relationship with surface and groundwater hydrology; another one in West Africa in Senegal (Roupsard et al., 2018; Faye et al., 2020), called Dakar'2030, dealing with the combination of rainwaters and wastewaters management in the Region of Dakar to water and re-green soils against soils and sea pollution.

\subsection{Databases}

Regarding the accessibility of data and open access data, the accent should be put on how to connect directly to existing web database, as well as to develop API to deal with connectivity issues. In some countries, even if there is open data, challenges refer to the infrastructure, as communication networks focus on mobile phone; the facility to upload data is not always there. It is necessary to address this, incl. the question of communication software. The world water data centres federated within the GTN-H (inter alia the Global Runoff Data Centre (GRDC), the GEMS/Water Data Centre for Water Quality (GWDC) the Global Groundwater Monitoring
Network (GGMN) operated by IGRAC) mostly operates under auspices of UN organization such as the WMO, UNEP or UNESCO and can guarantee long-term operational services to the scientific communities and local stakeholders worldwide since decades. These data centres should be recognized and considered for data rescue due to their long-term provision of homogenized and quality-assured in-situ observations. Vice versa FRIEND-Water communities could support the data centres in raising awareness of difficulties in data acquisition as well as lags in open data policies and technical requirements (e.g. APIs, provision of standards). Research is also necessary for link in-situ with satellite-born observations. Also, here FRIEND-Water could play a crucial role. Third action involves support to projects or initiatives with focus on surface water, river. Groundwater must not be forgotten, as well as interface areas like wetlands and coastal lagoons, as those play important role in the emission of GHGs. In addition, scaling should be addressed, as well spatial analysis of water data and other water-related data (uses, energy, virtual vs real, raw vs. reclaimed ...), at various scales, appropriate to the targets of communication. Implementation of experimental basins or watersheds is an interesting concept; in order to enable benchmarking, and use a methodology that can tackle multidisciplinary factors and approaches. Additionally, not only environmental settings, geopolitical settings, historical background, as well as demography and socio economic situations, but also water stress (considering surface and groundwater) should clearly be determined. Exchange of experiments, of data treatment, and also solutions could be organized through UNESCO Water family. Sharing data must become an open space in the entire UN Water family.

\section{Conclusion: toward the implementation of the IHP IX program}

The FWP is the most well know program from the IHP across the world. Since 36 years its success comes as well from its very large field of interest covering all topics of hydrology, than from its capacity to gather lot of people to share data, methods, tools and results in local to international events supported by the UNESCO Water Division. The FWP has developed a close relationship with the International Association of Hydrological Sciences-IAHS, which gives a scientific background to the program, and supports the publication of proceedings for each global conference. The FWP has changed over time, to follow the global directions given by the member States in each phase of the IHP program. The next IHP IX phase program will foster actions towards five main objectives: Scientific research and innovation; Water Education in the Fourth Industrial Revolution including sustainability; Bridging the data-knowledge gap; Inclusive water management under conditions of global change; Water Governance based on science for mitigation, adaptation 
and resilience. FWP, as the only transversal Water program of the IHP, will be able to support these five main objectives, both by launching regional initiatives towards a better integration of the multidimensional aspects of the water sciences including developed links with education, sustainability, governance, and so on, and by keeping a tight link with the IAHS scientific most recent outcomes and initiatives, as for instance the recent FRIEND-Water African Initiative (Mahe et al., 2020) to bring regional inputs to the 23 UPH - Unsolved Problems in Hydrology - (Bloschl et al., 2019).

Recently the FWP has been given the support of a Secretariat based in the UNESCO category 2 Center of Montpellier ICIREWARD. The next global FWP conference is scheduled in Dakar, Senegal in March 2023.

Data availability. No data sets were used in this article.

Author contributions. All autors contributed equally to this study, each one bringing the text for its region and or topic. GM prepared the frame of the paper and supervised the edition process of the paper.

Competing interests. The contact author has declared that neither they nor their co-authors have any competing interests.

Disclaimer. Publisher's note: Copernicus Publications remains neutral with regard to jurisdictional claims in published maps and institutional affiliations.

Special issue statement. This article is part of the special issue "Hydrology of Large River Basins of Africa". It is a result of the 4th International Conference on the "Hydrology of the Great Rivers of Africa", Cotonou, Benin, 13-20 November 2021.

\section{References}

Abdo, G.: Water management challenges in Sudan and how to meet them, Proceedings of the 7th Arab Forum for Scientific Research and Sustainable Development Amman - Jordan, 17-19 December, 2019.

Adeaga, O., Mahé, G., Dieulin, C., Elbaz-Poulichet, F., Rouché, N., Seidel, J. L., and Servat, E.: Quality of water resources in the Niger basin and in the region of Lagos (Nigeria), B. Geogr., 13, 51-60, https://doi.org/10.1515/bgeo-2017-0013, 2017.

Alsdorf, D., Beighley, E., Laraque, A., Lee, H., Tshimanga, R., O'Loughlin, F., Mahe, G., Dinga, B., Moukandi, G., and Spencer, R. G. M.: Opportunities for Hydrologic Research in the Congo Basin, Rev. Geophys., 54, 378-409, https://doi.org/10.1002/2016RG000517, 2016.
Amoussou, E.: Variabilité pluviométrique et dynamique hydrosédimentaire du bassin versant du complexe fluvio-lagunaire MonoAhémé-Couffo (Afrique de l'Ouest), Thèse de Doctorat unique, Université de Bourgogne, Dijon, France, CRCCNRS UMR5210, 313 pp., 2010.

Amoussou, E., Awoye, H., Totin Vodounon, H. S., Obahoundje, S., Camberlin, P., Diedhiou, A., Kouadio, K., Mahe, G., Houndenou, C., and Boko, M.: Climate and extreme rainfall events in the Mono river basin (West Africa): investigating future changes with regional climate models, Water, 12, 833, https://doi.org/10.3390/w12030833, 2020.

Amrouni, O., Sánchez, A., Khélifi, N., BenMoussa, T., Chiarella, D., Mahé, G., Abdeljaouad, S., and McLaren, P.: Sensitivity assessment of the deltaic coast of Medjerda based on fine-grained sediment dynamics, Gulf of Tunis (Western Mediterranean), J. Coast. Conserv., 23, 571-587, https://doi.org/10.1007/s11852019-00687-x, 2019.

André, M., Brou, Y. T., and Bigot, S.: Spatio-temporal variability of rainfall and impacts on vegetation in Reunion Island, 32nd Annual Conference of the South African Society for Atmospheric Sciences (SASAS), At Cape Town (South Africa), 30 October-2 November 2016, Cape Town, South Africa, 2016.

Basheer, M. and Elagib, N. A.: Temporal analysis of water-energy nexus indicators for hydropower generation and water pumping in the Lower Blue Nile Basin, J. Hydrol., 578, 124085, https://doi.org/10.1016/j.jhydrol.2019.124085, 2019.

Basheer, M., Wheeler, K., Ribbe, L., Abdo, G., and Zagona, E.: Quantifying and evaluating the impacts of cooperation in transboundary river basins on the Water-Energy-Food nexus: The Blue Nile Basin, Sci. Total Environ., 630, 1309-1323, 2018.

Basheer, M., Sulieman, R., and Ribbe, L.: Exploring management approaches for water and energy in the data-scarce TekezeAtbara Basin under hydrologic uncertainty, Int. J. Wat. Res. Dev., 37, 182-207, https://doi.org/10.1080/07900627.2019.1591941, 2019.

Beighley, E., Tshimanga, R. M., and N'Kaya, M. G.: Establishing science campaigns in sub-Saharan Africa, Eos, 100, https://doi.org/10.1029/2019EO117249, 2019.

Ben Moussa, T., Amrouni, O., Hzami, A., Dezileau, L., Mahe, G., Condomines, M., and Saadi, A.: Progradation and retrogradation of the Medjerda delta during the 20th century (Tunisia, Western Mediterranean), Comptes Rendus Geosciences, 341, 340-350, https://doi.org/10.1016/J.Crte.2018.10.004, 2019.

Blauhut, V., Gudmundsson, L., and Stahl, K.: Towards paneuropean drought risk maps: quantifying the link between drought indices and reported drought impacts, Environ. Res. Lett., 10, 014008, https://doi.org/10.1088/17489326/10/1/014008, 2015.

Blöschl, G., Bierkens, M. F. P., Chambel, A., Cudennec, C., Destouni, G., Fiori, A., Kirchner, J. W., McDonnell, J. J., Savenije, H. H. G., Sivapalan, M., Stumpp, C., Toth, E., Volpi, E., Carr, G., Lupton, C., Salinas, J., Széles, B., Viglione, A., Aksoy, H., Allen, S. T., Amin, A., Andréassian, V., Arheimer, B., Aryal, S. K., Baker, V., Bardsley, E., Barendrecht, M. H., Bartosova, A., Batelaan, O., Berghuijs, W. R., Beven, K., Blume, T., Bogaard, T., Borges de Amorim, P., Böttcher, M. E., Boulet, G., Breinl, K., Brilly, M., Brocca, L., Buytaert, W., Castellarin, A., Castelletti, A., Chen, X., Chen, Y., Chen, Y., Chifflard, P., Claps, P., Clark, M. P., Collins, A. L., Croke, B., Dathe, A., 
David, P. C., de Barros, F. P. J., de Rooij, G., Di Baldassarre, G., Driscoll, J. M., Duethmann, D., Dwivedi, R., Eris, E., Farmer, W. H., Feiccabrino, J., Ferguson, G., Ferrari, E., Ferraris, S., Fersch, B., Finger, D., Foglia, L., Fowler, K., Gartsman, B., Gascoin, S., Gaume, E., Gelfan, A., Geris, J., Gharari, S., Gleeson, T., Glendell, M., Gonzalez Bevacqua, A., González-Dugo, M. P., Grimaldi, S., Gupta, A. B., Guse, B., Han, D., Hannah, D., Harpold, A., Haun, S., Heal, K., Helfricht, K., Herrnegger, M., Hipsey, M., Hlaváciková, H., Hohmann, C., Holko, L., Hopkinson, C., Hrachowitz, M., Illangasekare, T. H., Inam, A., Innocente, C., Istanbulluoglu, E., Jarihani, B., Kalantari, Z., Kalvans, A., Khanal, S., Khatami, S., Kiesel, J., Kirkby, M., Knoben, W., Kochanek, K., Kohnová, S., Kolechkina, A., Krause, S., Kreamer, D., Kreibich, H., Kunstmann, H., Lange, H., Liberato, M. L. R., Lindquist, E., Link, T., Liu, J., Loucks, D. P., Luce, C., Mahé, G., Makarieva, O., Malard, J., Mashtayeva, S., Maskey, S., Mas-Pla, J., Mavrova-Guirguinova, M., Mazzoleni, M., Mernild, S., Misstear, B. D., Montanari, A., Müller-Thomy, H., Nabizadeh, A., Nardi, F., Neale, C., Nesterova, N., Nurtaev, B., Odongo, V. O., Panda, S., Pande, S., Pang, Z., Papacharalampous, G., Perrin, C., Pfister, L., Pimentel, R., Polo, M. J., Post, D., Prieto Sierra, C., Ramos, M.-H., Renner, M., Reynolds, J. E., Ridolfi, E., Rigon, R., Riva, M., Robertson, D. E., Rosso, R., Roy, T., Sá, J. H. M., Salvadori, G., Sandells, M., Schaefli, B., Schumann, A., Scolobig, A., Seibert, J., Servat, E., Shafiei, M., Sharma, A., Sidibe, M., Sidle, R. C., Skaugen, T., Smith, H., Spiessl, S. M., Stein, L., Steinsland, I., Strasser, U., Su, B., Szolgay, J., Tarboton, D., Tauro, F., Thirel, G., Tian, F., Tong, R., Tussupova, K., Tyralis, H., Uijlenhoet, R., van Beek, R., van der Ent, R. J., van der Ploeg, M., Van Loon, A. F., van Meerveld, I., van Nooijen, R., van Oel, P. R., Vidal, J.-P., von Freyberg, J., Vorogushyn, S., Wachniew, P., Wade, A. J., Ward, P., Westerberg, I. K., White, C., Wood, E. F., Woods, R., Xu, Z., Yilmaz, K. K., and Zhang, Y.: Twenty-Three Unsolved Problems In Hydrology (UPH) - A Community Perspective, Hydrol. Sci. J., 64, 11411158, https://doi.org/10.1080/02626667.2019.1620507, 2019.

Bogning, S., Frappart, F., Paris, A., Blarel, F., Niño, F., Saux Picart, S., Lanet, P., Seyler, F., Mahé, G., Onguene, R., Bricquet, J. P., Etame, J., Paiz, M. C., and Braun, J. J.: Hydroclimatology study of the Ogooué River basin using hydrological modeling and satellite altimetry, Adv. Space Res., 68, 672-690, https://doi.org/10.1016/j.asr.2020.03.045, 2020.

Boussougou, G., Brou, Y. T., and Mohamed, I.: Changements de la couverture forestière dans l'île d'Anjouan entre 1995 et 2014, Proceedings of the Spatial Analysis and GEOmatics conference, SAGEO 2015, 194-207, 2017.

Brou, Y. T.: Coviability of the social and ecological systems in Réunion Island's National Park: Climate variability, wildfires, and the vulnerability of biodiversity, in: Co-viability of Social and Ecological Systems, reconnect Human with Biosphere, edited by: Barière, O. and Behnassi, M., Edition Springer, 2, 187-202, https://doi.org/10.1007/978-3-319-78497-7, 2019.

Brou, Y. T., Vololonirainy, R., Boussougou, G., Raharinjanahary, R., Bigot, S., Dumas, S., Ramboarison, R., Razanaka, S., Parany, L., Rakotoarijaona, M., Herve, D., and Rakotoarijaona, J. R.: Pressions agro-démographiques et état de l'occupation des sols dans l'espace protégé d'Ankarafantsika: bilan cartographique et paysager, Carnet de Recherche de l'Océan Indien, Université no. 2, 1-13, 2018.
Caillouet, L., Vidal, J.-P., Sauquet, E., Graff, B., and Soubeyroux, J.-M.: SCOPE Climate: a 142-year daily high-resolution ensemble meteorological reconstruction dataset over France, Earth Syst. Sci. Data, 11, 241-260, https://doi.org/10.5194/essd-11241-2019, 2019.

Carr, A. B., Trigg, M. A., Tshimanga, R. M., Borman, J. D., and Smith, M. W.: Greater Water Surface Variability Revealed by New Congo River Field Data: Implications for Satellite Altimetry Measurements of Large Rivers, Geophys. Res. Lett., 46, 8093-8101, https://doi.org/10.1029/2019GL083720, 2019.

Carretier, S., Tolorza, V., Regard, V., Aguilar, V., Bermudez, M.A., Martinod., J., Guyot, J. L., Herail, G., and Riquelme, R.: Review of erosion dynamics along the major N-S climatic gradient in Chile and perspectives, Geomorphology, 300, 45-68, https://doi.org/10.1016/j.geomorph.2017.10.016, 2018.

Descroix, L., Guichard, F., Grippa, M., Lambert, L., Panthou, J., Mahe, G., Gal, L., Dardel, C., Quantin, G., Kergoat, L., Bouaita, Y., Hiernaux, P., Vischel, T., Pellarin, T., Faty, B., Wilcox, C., Malam Abdou, M., Mammadou, I., Bandervaere, J. P., Diongue-Niang, A., Ndiaye, O., Sane, Y., Dacosta, H., Gosset, M., Casse, C., Sultan, B., Barry, A., Amogu, O., Nka Nnomo, B., Barry, A., and Paturel, J. E.: Surface hydrology evolution in the Sahelo-Sudanian stripe: An updated review, Water, 10, 748, https://doi.org/10.3390/w10060748, 2018.

Devers, A., Vidal, J.-P., Lauvernet, C., Graff, B., and Vannier, O.: A framework for high-resolution meteorological surface reanalysis through offline data assimilation in an ensemble of downscaled reconstructions, Q. J. Roy. Meteor. Soc., 146, 153-173, https://doi.org/10.1002/qj.3663, 2020.

Dieppois, B., Durand, A., Fournier, M., and Massei, N.: Links between multidecadal and interdecadal climatic oscillations in the North Atlantic and regional climate variability of northern France and England since the 17th century, J. Geophys. Res.-Atmos., 118, 4359-4372, 2013.

Dieppois, B., Pohl, B., Crétat, J., Eden, J., Sidibe, M., New, M., Rouault, M., and Lawler, D.: Southern African summer-rainfall variability, and its teleconnections, on interannual to interdecadal timescales in CMIP5 models, Clim. Dynam., 53, 3505-3527, https://doi.org/10.1007/s00382-019-04720-5, 2019.

Dieulin, C., Mahe, G., Paturel, J. E., Ejjiyar, S., Tramblay, Y., Rouche, N., and El Mansouri, B.: A new 60-year 1940-1999 monthly gridded rainfall data set for Africa, Water, 11, 387, https://doi.org/10.3390/w11020387, 2019.

Dubois, C., Stoffner, F., Kalia, A. C., Sandner, M., Labiadh, M., and Mimouni, M.: COPERNICUS SENTINEL-2 data for the determination of groundwater withdrawal in the Maghreb region, ISPRS Ann. Photogramm. Remote Sens. Spatial Inf. Sci., IV-1, 37-44, https://doi.org/10.5194/isprs-annals-IV-1-37-2018, 2018.

Erostate, M., Huneau, F., Garel, E., Ghiotti, S., Vystavna, Y., Garrido, M., and Pasqualini, V.: Groundwater dependent ecosystems in coastal Mediterranean regions: Characterization, challenges and management for their protection, Water Res., 172, 115461, https://doi.org/10.1016/j.watres.2019.115461, 2020.

Faye, W., Orange, D., Roupsard, O., Do, F. C., Jourdan, C., Fall, A. N., Kane, A., N'diénor, M., Angulo-Jaramillo, R., Lassabatère, L., Di Prima, S., Sauvage, S., and Sanchez-Perez, J.: Ecohydrology and agroforestry for water use efficiency on sahelian agrosystem: the Sine River Basin, In: 4th International confer- 
ence on Hydrology of African Large River Basins, FRIENDAOC, Cotonou, Bénin, 6 pp., 24-28 November 2020.

Ferreira Araújo, D., Peres, L. G. M., Yepez, S., Mulholland, D. S., Machado, W., Tonha, M., and Garnier, J.: Assessing maninduced environmental changes in the Sepetiba Bay (Southeastern Brazil) with geochemical and satellite data, Comptes Rendus Geoscience, 349, 290-298, 2017.

Gallay, M., Martinez, J. M., Mora, A., Castellano, B., Yepez, S., Cochonneau, G., Alfonso, J. A., Carrera, J. M., Lopez, J. L., and Laraque, A.: Assessing Orinoco river sediment discharge trend using MODIS satellite images, J. South Am. Earth Sci., 91, 320331, https://doi.org/10.1016/j.jsames.2019.01.010, 2019.

Hadour, A., Meddi, M., and Mahe, G.: Impact of climate change on the hydrology of North-Western Algeria, J. Hydrol. Reg. Stud., 28, https://doi.org/10.1016/j.ejrh.2020.100671, 2020.

Hallouz, F., Meddi, M., Mahe, G., Toumi, S., and Ali Rahamni, S. E.: Erosion, sedimentation and climate change on the Wadi Mina at the Sidi M'hamed Ben Aouda dam, Algeria, Water, 10, 895, https://doi.org/10.3390/w10070895, 2018.

Hang, H. T. T., Thuy, D. T., Kien, N. T., Le, T. P. Q., Minh, L. T. N., Duc, T. A., Anh, L. H., Cuong, H. T., Kim, D. D., Nemery, J., Orange, D., and Klein, J.: Impact of anthropogenic activities on water quality and plankton communities in the Day River (Red River Delta, Vietnam), Environ. Monit. Assess., 190, 67, https://doi.org/10.1007/s10661-017-6435-z, 2018.

Hartmann, A., Gleeson, T., Wada, Y., and Wagener, T.: Enhanced groundwater recharge rates and altered recharge sensitivity to climate variability through subsurface heterogeneity, P. Natl. Acad. Sci. USA, 114, 2842-2847, https://doi.org/10.1073/pnas.1614941114, 2017.

Hiraga, Y., Kazama, S., Ekkawatpanit, C., and Touge, Y.: Impact of reclamation on the environment of the lower Mekong river basin, J. Hydrol., 18, 143-155, 2018.

Hoa, N. T. Q., Anh, H. Q., Tue, N. M., Trung, N. T., Da, L. N., Van Quy, T., Huong, N. T. A., Suzuki, G., Takahashi, S., Tanabe, S., Thuy, P. C., Dau, P. T., Viet, P. H., and Thuyen, L. H.: Soil and sediment contamination by unsubstituted and methylated polycyclic aromatic hydrocarbons in an informal e-waste recycling area, northern Vietnam: occurrence, source apportionment, and risk assessment, Sci. Total Environ., 709, 135852, https://doi.org/10.1016/j.scitotenv.2019.135852, 2020.

IPCC: Climate Change 2013: The Physical Science Basis. Contribution of Working Group I to the Fifth Assessment Report of the Intergovernmental Panel on Climate Change, edited by: Stocker, T. F., Qin, D., Plattner, G.-K., Tignor, M., Allen, S. K., Boschung, J., Nauels, A., Xia, Y., Bex, V., and Midgley, P. M., Cambridge University Press, Cambridge, United Kingdom and New York, NY, USA, 1535 pp., https://doi.org/10.1017/CBO9781107415324, 2013.

Johansson, E. L. and Abdi, A. M.: Mapping and quantifying perceptions of environmental change in Kilombero Valley, Tanzania, Ambio, 49, 557-568, 2020.

Khater, C., Fenianos, J., Brouillet, D., and Arnaud, N.: Bridging Ecological Rehabilitation and Socio Cognitive Psychology, International Journal of Environmental Sciences \& Natural Resources, Juniper Publishers Inc., 17, 2, 39-42, 2019.

Kingston, D. G., Massei, N., Dieppois, B., Hannah, D. M., Hartman, A., Lavers, D. A., and Vidal, J. P.: Moving beyond the catchment scale: Value and opportunities in large-scale hydrology to un- derstand our changing world, Hydrol. Process., 34, 2292-2298, https://doi.org/10.1002/hyp.13729, 2020.

Kondolf, G., Schmitt, M., Rafael, J. P., Carling, P., Darby, S., Arias, M., Bizzi, S., Castelletti, A., Cochrane, T. A., Gibson, S., Kummu, M., Oeurng, C., Rubin, Z., and Wild, T.: Changing sediment budget of the Mekong: Cumulative threats and management strategies for a large river basin, Sci. Total Environ., 1, 625, 114-134, 2018.

Kositgittiwong, D., Ekkawatpanit, C., Chiawyonsin, S., Petpongpan, C., and Ekkphisutsuntorn, P.: Development of wetland water management in Bueng Takreng, Thailand, Wetland Research, 7, 25-31, 2017.

Kotti, F., Dezileau, L., Mahe, G., Habaieb, H., Benabdallah, S., Bentkaya, M., Calvez, R., and Dieulin, C.: The impact of dams and climate on the evolution of the sediment loads to the sea by the Medjerda River using a paleohydrological approach, J. Afr. Earth Sci., 142, 226-233, https://doi.org/10.1016/j.jafrearsci.2017.10.003, 2018.

Kuper, M., Leduc, C., Massuel, S., and Bouarfa, S.: Topical collection: Groundwater-based agriculture in the Mediterranean, Hydrogeol. J., 25, 1525-1528, https://doi.org/10.1007/s10040-0171598-9, 2017.

Kuper, M., Naouri, M., and Hartani, T.: Agriculture in motion: Intertwined geographical and socio-professional mobilities in North Africa's groundwater economy, Meltem, 4, 33-45, https://doi.org/10.32325/iaad.2018.31, 2018.

Laizé, C. and Hannah, D. M.: Modification of climate-river flow associations by basin properties, J. Hydrol., 389, 186-204, https://doi.org/10.1016/j.jhydrol.2010.05.048, 2010.

Laqui, W., Zubieta, R., Rau, P., Mejia, A., Lavado, W., and Ingol, E.: Can artificial neural networks estimate potential evapotranspiration in Peruvian highlands?, Model. Earth Syst. Environ., 5, 1911-1924, 2018.

Laraque A., Lopez, J. L., Yepez, S., and Georgescu, P.: Water and Sediment Budget of Casiquiare Channel Linking Orinoco and Amazon Catchments, Venezuela, Water, 11, 2068, https://doi.org/10.3390/w11102068, 2019.

Lavers, D.A., Zsoter, E., Richardson, D. S., and Pappenberger, F.: An assessment of the ECMWF extreme forecast index for water vapor transport during boreal winter, Weather Forecast., 32, 1667-1674, https://doi.org/10.1175/WAF-D-17-0073.1, 2017.

Le, T. P. Q., Dao, V. N., Rochelle-Newall, E., Garnier, J., Lu, X. X., Billen, G., Duong, T. T., Ho, C. T., Etcheber, H., Nguyen, T. M. H., Nguyen, T. B. N., Nguyen, B. N., Le, N. D., and Long, P. Q.: Total organic carbon fluxes of the Red River system (Vietnam), Earth Surf. Proc. Landf., 42, 1329-1341, https://doi.org/10.1002/esp.4107, 2017.

Le Gros, C., Sauquet, E., Lang, M., Achard, A. L., Leblois, E., and Biton, B.: The hydrological yearbooks published by the Société Hydrotechnique de France: A valuable source of information on hydrology in France, La Houille Blanche, 4, 66-77, https://doi.org/10.1051/lhb/20150048, 2015.

Li, D. F., Lu, X. X., Yang, X., Chen, L., and Lin, L.: Sediment load responses to climate variation and cascade reservoirs in the Yangtze River: A case study of the Jinsha River, Geomorphology, 322, 41-52, 2018.

Mahe, G., Ogilvie, A., Servat, E., and Ardoin-Bardin, S.: 23 UPH in Africa, gathering the contributions of the African hydrologists to the 23 Unsolved Problems in Hydrology, of the IAHS, available 
at: https://www.researchgate.net/project/23-UPH-in-Africa (last access: 6 January 2021), 2020.

Marignani, M., Bruschi, D., Astiaso Garcia, D., Frondoni, R., Carli, E., Pinna, M. S., Cumo, F., Gugliermetti, F., Saatkamp, A., Doxa, A., Queller, E. M., Chaieb, M., Bou DagherKharrat, M., El Zein, R., El Jeitani, S., Khater, C., Mansour, S., Al-Shami, A., Harik, G., Alameddine, I., El-Fadel, M., and Blasi, C.: Identification and prioritization of areas with high environmental risk in Mediterranean coastal areas: a flexible approach, Sci. Total Environ., 590-591, 566-578, https://doi.org/10.1016/j.scitotenv.2017.02.221, 2017.

Massei, N., Kingston, D. G., Hannah, D. M., Vidal, J. P., Dieppois, B., Fossa, M., Hartmann, A., Lavers, D. A., and Laignel, B.: Understanding and predicting large-scale hydrological variability in a changing environment, 8Th Global FRIEND Water conference "Hydrological Processes and Water Security in a Changing World", Beijing, China, 6-9 November 2018.

Moquet, J. S., Guyot, J. L., Morera, S., Crave, A., Rau, P., Vauchel, P., Lagane, C., Sondag, F., Lavado, C. W., Pombosa, R., and Martinez, J. M.: Temporal variability and annual budget of inorganic dissolved matter in Andean Pacific Rivers located along a climate gradient from northern Ecuador to southern Peru, C.R. Geo. 350, 76-87, https://doi.org/10.1016/j.crte.2017.11.002, 2018.

Mushi, C. A., Ndomba, P. M., Trigg, M. A., Tshimanga, R. M., and Mtalo, F.: Assessment of basin-scale soil erosion within the Congo River Basin: A review, Catena, 178, 64-76, https://doi.org/10.1016/j.catena.2019.02.030, 2019.

Mzava, P., Nobert, J., and Valimba, P.: Land Cover Change Detection in the Urban Catchments of Dar es Salaam, Tanzania using Remote Sensing and GIS Techniques, Tanzania J. Sci., 45, 315329, 2019.

Nardini, A., Yepez, S., Zuniga, L., Gualtieri, C., and Bejarno, M. D.: A Computer Aided Approach for River Styles - Inspired Characterization of Large Basins: The Magdalena River (Colombia), Water, 12, 1147, https://doi.org/10.3390/w12041147, 2020.

Nguyen, T. X., Nguyen, B. T., Tran, H. T. T., Mai, H., Duong, T. T., and Bach, Q. V.: Seasonal, spatial variation, and potential sources of organochlorine Pesticides in Water and Sediment in the Lower Reaches of the Dong Nai River System in Vietnam, Archives of Environmental Contamination and Toxicology, 77, 514-526, 2019.

Orange, D. and Breil, P.: Integrated watershed management including eco-hydrology and socio-hydrology: Ecological and societal based approaches for watershed management, Introduction text of Session 6 for: Hydrological Processes and Water Security in a Changing World, FRIEND-Water 2018: 8th Global FRIENDWater Conference, Beijing, China, 6-9 November 2018, 1 pp., 2018.

Parkes, B., Cronin, J., Dessens, O., and Sultan, B.: Climate change in Africa: costs of mitigating heat stress, Clim. Change, 154, 461-476, 2019.

Prudhomme, C., Giuntoli, I., Robinson, E. L., Clark, D. B., Arnell, N. W., Dankers, R., Fekete, B. M., Franssen, W., Gerten, D., Gosling, S. N., Hagemann, S., Hannah, D. M., Kim, H., Masaki, Y., Satoh, Y., Stacke, T., Wada, Y., and Wisser, D.: Hydrological droughts in the 21 st century, hotspots and uncertainties from a global multimodel ensemble experiment, P. Natl. Acad. Sci., 111, 3262-3267, https://doi.org/10.1073/pnas.1222473110, 2014.
Rau, P., Bourrel, L., Labat, D., Frappart, F., Ruelland, D., Lavado, W., Dewitte, B., and Felipe, O.: Hydroclimatic change disparity of Peruvian Pacific drainage catchments, Theor. Appl. Climatol., 134, 139-153, 2018.

Reca-Cardena, J. and Lopez-Luque, R.: Chapter 9 - Design Principles of Photovoltaic Irrigation Systems, Advances in Renewable Energies and Power Technologies, Solar and Wind Energies, 1, 295-333, https://doi.org/10.1016/B978-0-12-812959-3.00009-5, 2018.

Renard, B. and Thyer, M.: Revealing hidden climate indices from the occurrence of hydrologic extremes, Water Resour. Res., 55, 7662-7768, https://doi.org/10.1029/2019WR024951, 2019.

Riaux, J., Orange, D., Ogilvie, A., Leduc, C., Mohamed, A. S., Ali, H. M., Sidatt, Z. A., and Wesselink, A.: Une démarche sociohydrologique pour renouveler les savoirs sur le fleuve Sénégal, Colloque International PATEO/UASZ : Vulnérabilité des sociétés et des milieux côtiers et estuariens d'Afrique de l'Ouest, UASZ, Ziguinchor, Sénégal, 19-22 November 2019, Coll. Livres UASZ, 6 pp., 2020.

Roupsard, O., Jourdan, C., Cournac, L., Ndour, B. Y., Tall, L., Chapuis-Lardy, L., Clermont-Dauphin, C., Orange, D., Do, F., Kergoat, L., Le Maire, G., Van der Meersche, K., Timouk, F., Grippa, M., Rocheteau, A., Duthoit, M., Chotte, J. L., and Laclau, J. P.: "Faidherbia-Flux", a new highly instrumented collaborative Observatory in a semi-arid agro-sylvo-pastoral system of Western Africa (Niakhar-Senegal), Int. Conf. ANAEE, session: challenges and opportunities of long-term ecosystem experiments in forests, Functional Ecology, Nancy, 10-13 December 2018, 1 pp., 2018

Salih, A.: Water Resources in Sudan, Book, Water Research Center, Univ. of Khartoum, Sudan, 2018.

Salih, A.: Coping with water scarcity in the Arab Region, Proceedings of the 7th Arab Forum for Scientific Research and Sustainable Development Amman - Jordan, 17-19 December 2019.

Sidibe, M., Dieppois, B., Mahe, G., Paturel, J. E., Amoussou, E., Anifowose, B., and Lawler, D.: Trend And Variability In A New, Reconstructed Streamflow Dataset For West And Central Africa, And Climatic Interactions, 1950-2005, J. Hydrol., 561, 478-493, https://doi.org/10.1016/j.jhydrol.2018.04.024, 2018.

Sidibe, M., Dieppois, B., Eden, J., Mahé, G., Paturel, J. E., Amoussou, E. Anifowose, B., and Lawler, D.: Interannual to multi-decadal streamflow variability in west and Central Africa: Interactions with catchment properties and largescale climate variability, Glob. Planet. Change, 177, 141-156, https://doi.org/10.1016/j.gloplacha.2019.04.003, 2019.

Sidibe, M., Dieppois, B., Eden, J., Mahe, G., Paturel, J. E., Amoussou, E., Anifowose, B., Van de Wiel, M., and Lawler, D.: Impacts of near-term climate change on hydrological systems in West and Central Africa, Clim. Dynam., 54, 2041-2070, https://doi.org/10.1007/s00382-019-05102-7, 2020.

Stahl, K., Tallaksen, L. M., Hannaford, J., and van Lanen, H. A. J.: Filling the white space on maps of European runoff trends: estimates from a multi-model ensemble, Hydrol. Earth Syst. Sci., 16 2035-2047, https://doi.org/10.5194/hess-16-2035-2012, 2012.

Stahl, K., Kohn, I., Blauhut, V., Urquijo, J., De Stefano, L., Acácio, V., Dias, S., Stagge, J. H., Tallaksen, L. M., Kampragou, E., Van Loon, A. F., Barker, L. J., Melsen, L. A., Bifulco, C., Musolino, D., de Carli, A., Massarutto, A., Assimacopoulos, D., and Van Lanen, H. A. J.: Impacts of European drought events: insights 
from an international database of text-based reports, Nat. Hazards Earth Syst. Sci., 16, 801-819, https://doi.org/10.5194/nhess16-801-2016, 2016.

Stoelzle, M., Stahl, K., Morhard, A., and Weiler, M.: Streamflow sensitivity to drought scenarios in catchments with different geology, Geophys. Res. Lett., 41, 6174-6183, https://doi.org/10.1002/2014GL061344, 2014.

Sutanto, S. J., van der Weert, M., Wanders, N., Blauhut, V., and Van Lanen, H. A. J.: Moving from drought hazard to impact forecasts, Nat. Commun., 10, 4945, https://doi.org/10.1038/s41467019-12840-z, 2019a.

Sutanto, S. J., Vitolo, C., Di Napoli, C., D'Andrea, M., and Van Lanen, H. A. J.: Heatwaves, droughts, and fires: exploring compound and cascading dry hazards at the pan-European scale, Environ. Int., 134, 105276, https://doi.org/10.1016/j.envint.2019.105276, 2019b.

Teuling, G. A. J., Tallaksen, L. M., Uijlenhoet, R., Hannah, D. M., Sheffield, J., Svoboda, M., Verbeiren, B., Wagener, T., Rangecroft, S., Wanders, N., and Van Lanen, H. A. J.: Drought in the Anthropocene, Nat. Geosci., 9, 89-91, https://doi.org/10.1038/ngeo2646, 2016.

Tramblay, Y. and Somot, S.: Future evolution of extreme precipitation in the Mediterranean, Clim. Change, 151, 289-302, 2018.

Trigg, A. M. and Tshimanga, R. M.: Capacity Building in the Congo Basin: Rich Resources Requiring Sustainable Development, One Earth 2, 2020 Elsevier Inc, https://doi.org/10.1016/j.oneear.2020.02.008, 2020.

Try, S., Lee, G., Yu, W., Oeurng, C., and Jang, C.: Large-scale Flood Inundation Modeling in the Mekong River Basin, J. Hydrol. Eng., 23, 05018011, https://doi.org/10.1186/s40645-02000353-z, 2018.

Tshimanga, R. M., Bola, G., Kabuya, P., Nkaba, L., Neal, J., Hawker, L., Trigg, A. M., Bates, P., Hughes, A. D., Laraque, A., Woods, R., and Wagener, T.: Towards a framework of catchment classification for hydrologic predictions and water resources management in the ungauged basin of the Congo River: An a priori approach, AGU Monograph, in press, 2021.

Uk, S., Chihiro, Y., Sokly, S., Try, S., Heejun, Y., Oeurng, C., Shanghang, L., and Seingheng, H.: Tonle Sap Lake: Current Status and Important Research Directions for Environmental Management, Lakes Reservoirs, 23, 1-13, 2018.

UNESCO: Science for a Water Secure World in a Changing Environment, Draft IHP-IX Strategic Plan, The ninth phase of the Intergovernmental Hydrological Programme 2022-2029, Paris, 4 June 2021, available at: https://en.unesco.org/sites/default/files/ ihp-ic-xxiv-ref.1_ihp-ix_strategic_plan.pdf (last access: 6 January 2021), 2021.

Van Lanen, H. A. J., Wanders, N., Tallaksen, L. M., and Van Loon, A. F.: Hydrological drought across the world: impact of climate and physical catchment structure, Hydrol. Earth Syst. Sci., 17, 1715-1732, https://doi.org/10.5194/hess-17-1715-2013, 2013.
Van Loon, A. F., Gleeson, T., Clark, J., Van Dijk, A. I. J. M., Stahl, K., Hannaford, J., Di Baldassarre, G., Teuling, A. J., Tallaksen, L. M., Uijlenhoet, R., Hannah, D. M., Sheffield, J., Svoboda, M., Verbeiren, B., Wagener, T., Rangecroft, S., Wanders, N., and Van Lanen, H. A. J.: Drought in the Anthropocene, Nat. Geosci., 9, 89-91, https://doi.org/10.1038/ngeo2646, 2016.

Venot, J. P., Kuper, M., and Zwarteveen, M.: Drip Irrigation: Untold Stories of Efficiency, Innovation \& Development, Earthscan, Routledge, London, 2017.

Wei, X., Sauvage, S., Le, T. P. Q., Ouillon, S., Orange, D., Vu, D. V., and Sanchez-Perez, J.-M.: A modelling approach to diagnose the impacts of global changes on discharge and suspended sediment concentration within the Red River basin, Water, 11, 958, https://doi.org/10.3390/w11050958, 2019.

Wheeler, K., Hall, J. W., Abdo, G., Dadson, S. J., Kasprzyk, J. R., Smith, R., and Zagona, E. A.: Exploring Cooperative Transboundary River Management Strategies for the Eastern Nile Basin, Water Resour. Res., 54, 9224-9254, 2018.

Xi, W., Sauvage, S., Le, T. P. Q., Ouillon, S., Orange, D., Vinh, V. D., and Sanchez Perez, J. M.: A modelling approach to diagnose the impacts of global changes on discharge and suspended sediment concentration within the Red River basin, Water, 11, 958, https://doi.org/10.3390/w11050958, 2019.

Yang, X. K., Lu, X. X., Park, E., and Tarolli, P.: Impacts of Climate Change on Lake Fluctuations in the Hindu Kush-Himalaya-Tibetan Plateau, Remote Sens., 11, 1082, https://doi.org/10.3390/rs11091082, 2019.

Yepez, S., Laraque, A., Martinez, J. M., Sa, J. D., Carrera, J. M., Castellanos, B., Gallay, M., and Lopez, J. L.: Retrieval of suspended sediment concentrations using Landsat-8 OLI satellite images in the Orinoco River (Venezuela), Comptes Rendus Geoscience, 350, 20-30, https://doi.org/10.1016/j.crte.2017.08.004, 2018.

Yepez, S. P., Laraque, A., Gualtieri, C., Christophoul, F., Marchan, C., Castellanos, B., Azocar, J. M., Lopez, J. L., and Alfonso, J.: Morphodynamic change analysis of bedforms in the Lower Orinoco River, Venezuela, Proc. IAHS, 377, 41-50, https://doi.org/10.5194/piahs-377-41-2018, 2018.

Zare, A., Barbier, B., Bologo Traore, M., Diarra, A., Mahe, G., and Paturel, J. E.: Climate Forecast perception and needs in Wetlands: A Case Study of the Inner Niger Delta in Mali, Wetlands, 37, 913-923, https://doi.org/10.1007/s13157-017-0926-0, 2017.

Zhang, S. R., Bai, Y. J., Wen, X., Ding, A., and Zhi, J. H.: Seasonal and downstream alterations of dissolved organic matter and dissolved inorganic ions in a human-impacted mountainous tributary of the Yellow River, China, Environ. Sci. Pollut. Res., 25, 17967-17979, 2018. 